\title{
Assessment of Parasites and Bacterial Contamination of Office Door Handles in Nnamdi Azikiwe University, Awka, Anambra State
}

\author{
Pauline Ukamaka Umeanaeto ${ }^{1}$, Ugochukwu Chukwuma Okafor ${ }^{2}$, Miracle Chisom Unam ${ }^{2}$, \\ Chidiogo Chidimma Ilo ${ }^{1}$, Chukwudinma Chigozie Okoli ${ }^{3}$, Stella Chinyere Afulukwe ${ }^{4}$, \\ Nnamdi Enoch Nwakoby \\ ${ }^{1}$ Department of Parasitology and Entomology, Faculty of Biosciences, Nnamdi Azikiwe University, Awka, Nigeria \\ ${ }^{2}$ Department of Applied Microbiology and Brewing, Faculty of Biosciences, Nnamdi Azikiwe University, Awka, Nigeria \\ ${ }^{3}$ Hospital Management Board, Laboratory Unit, Kuje General Hospital, FCTA, Abuja \\ ${ }^{4}$ Department of Anatomy, Chukwuemeka Odumegwu Ojukwu University, Uli, Nigeria \\ ${ }^{5}$ Department of Microbiology, Faculty of Natural Sciences, Chukwuemeka Odumegwu Ojukwu University, Uli, Nigeria
}

Email address:

pu.umeanaeto@unizik.edu.ng (P. U. Umeanaeto)

\section{To cite this article:}

Pauline Ukamaka Umeanaeto, Ugochukwu Chukwuma Okafor, Miracle Chisom Unam, Chidiogo Chidimma Ilo, Chukwudinma Chigozie Okoli, Stella Chinyere Afulukwe, Nnamdi Enoch Nwakoby. Assessment of Parasites and Bacterial Contamination of Office Door Handles in Nnamdi Azikiwe University, Awka, Anambra State. American Journal of Biomedical and Life Sciences. Vol. 9, No. 2, 2021 , pp. $120-127$. doi: $10.11648 /$ j.ajbls.20210902.13

Received: March 11, 2021; Accepted: April 19, 2021; Published: April 29, 2021

\begin{abstract}
Microorganisms are present on all surfaces, to which they were carried by many direct and indirect methods of transmission. Bacteria and Parasites contaminating office door handles in Nnamdi Azikiwe University were assessed between June and November, 2019. The buildings and the door handles were randomly selected. Sterile swabs moistened in sterile normal saline were used to swab the door handles in a tri-directional manner. The swabs were cultured and subcultured onto nutrient, MacConkey and Salmonella-Shigella agar plates for bacterial growth. The specimens were then examined for parasites using Zinc Sulphate floatation and formol-ether sedimentation techniques. Of the 432 door handles examined, 136 $(30.8 \%)$ were contaminated. The highest number of contaminated doors were found in Medical Centre $41(30.1 \%)$ and the least in Faculty of Social Sciences Complex 10 (7.4\%). E. histolytica 52 (38.2\%) was the highest parasite encountered while E. vermicularis $2(1.5 \%)$ was the least. The proportion of infected doors as well as the distribution of different species parasites in the door handles of different complexes examined was significant $(\mathrm{P}<0.05)$. Of 432 office door handles examined, 263 $(60.9 \%)$ yielded bacterial growth. Female hostel $72(27.4 \%)$ had more bacterial contamination while Faculty of Social Sciences 25 (9.5\%) had the least. Staphylococcus spp 54 (20.5\%) was the highest bacteria isolated, followed by Escherichia 53 (20.2\%) while Klebsiella $53(20.2 \%)$ was the least. The distribution of different species of bacteria in the door handles in different complexes was significant $(\mathrm{P}<0.05)$. Infectious diseases from microbial contaminated door handles are a potential threat to public health and safety therefore certain measures should be taken such as aggressive and frequent cleaning methods and good hand washing to reduce the incidence of bacterial and parasite transmission and contamination.
\end{abstract}

Keywords: Bacteria, Parasites, Contamination, Door Handles

\section{Introduction}

Microorganisms are widespread in nature constituting a major part of every ecosystem. Bacteria, fungi, parasites and viruses contaminate the body, houses, work places and whole environment. They are beneficial to life but some are dangerous to health, causing different diseases [1]. Microbial contaminations are widely reported in different indoor and outdoor environments.

Human societies have always been challenged by 
infectious diseases caused by bacteria, fungi, virus, helminth and protozoan parasites with pathogenic parasites producing cysts, oocysts and ova on contact surfaces [2]. These infectious microorganisms can be found in any environment including soil, air, water and food. While pathogens are sometimes transmitted by direct contact between infected and susceptible individuals, the environment is often an important mediator of transmission [3]. Environmental surfaces or objects act as a reservoir for proliferation of microorganisms $[4,5]$. One major source of spread of community acquired infections are fomites $[6,7]$. Fomites exposure requires an inanimate object or material to carry a pathogen from one susceptible animal or object to another. It often involves secondary route of exposure such as oral or direct contact for pathogen to enter the host, both enteric and respiratory pathogens [8].

Fomites when in constant contact with humans or natural habitats of pathogenic organism constitute a major source of spread of infectious diseases [9.10]. Such fomites include door handles or knobs, showers, toilet seats and faucets, sinks, lockers, chairs, and tables, especially those found in public offices, hospitals, hotels, restaurants and restrooms; others include contaminated vehicles, utensils, towels, pen, shovels, clothing, money, books, toys, bowls/buckets, brushes, tacks and clippers [10]. There is increasing evidence that contaminated inanimate surfaces and especially those frequently touched by hands can contribute to the spread of healthcare associated pathogens from place to place and from person to person [11].

It has been reported that bacteria can survive for variable duration on surfaces of fomites $[12,13]$. Risk of transmission is directly proportional to the duration of survival of the bacteria on the colonized objects. The colonization and survival depend on geographical and environmental conditions like temperature, humidity, presence of organic matter, ability to form biofilms and the prevalent infection control practices $[14,15]$. Gram positive and Gram negative bacteria have been reported to survive up to months on dry inanimate surfaces in the hospitals [14].

Door knob is one of the most common fomite that serves as a route for contamination [16]. It has been shown that hard, non-porous surfaces such as door handles, have the highest bacterial transfer rates to hands [17]. Bacterial pathogens that have been isolated from door knobs in previous studies include; Staphylococcus. aureus, Klebsiella pneumoniae, Escherichia coli, Enterobacter sp, Citrobacter sp, Pseudomonas aeruginosa, Proteus sp, Streptococcus, Salmonella sp, Shigella sp, Campylobacter sp [18, 19]. These organisms have been known to cause one or more diseases that are mild and could sometimes be serious. Examples are but not limited to pimple, impetigo, scalded skin syndrome, pneumonia, meningitis, osteomyelitis, rhinoscleroma, kidney failure, septicemia [20, 21].

In the university environment, students, staff and visitors have access to service offices regularly for different purposes. Given that the door handles are not routinely disinfected, the opportunity for the transmission of contaminating microorganisms is great. Doors have large traffic users, who throng in with pathogens they have picked elsewhere and deposit them on the handles while going in and out [22]. As people come in contact with surfaces as desks, keyboards and office furniture and toilet and office lock handles, there is the possibility of picking up microbes deposited on them. The toilet and office lock handles are in contact more frequently with their users and visitors, especially public toilets and offices. They are commonly touched by hands, which may act as sources for transfer [11].

Most intestinal parasites have their infective stages transmitted by faeco-oral route. Faecal-oral transmission involves the ingestion of food or water contaminated with cysts or oocysts available in the immediate environment. The faeco-oral route is significant in transmission of parasitic infections to human through poor hygiene. When soil becomes contaminated, the eggs in the soil can be transferred onto vegetables, door handles and onto the hands from where it is transferred to the mouth [23]. These organisms can infect about 50 million people, killing about 100,000 people yearly [24]. About $85 \%$ of people infected with intestinal parasites are healthy carriers [25], with consequences of more transmission by faecal-oral route or human-to-human [26]. These Parasites are infective to humans, causing varying pathogenic conditions such as in intestinal and extra intestinal infection such as amoebiasis, cryptosporidiosis, giardiasis, ascariasis and several more leading to enteric diseases [27].

The Nigeria environment has been described as poor, based on personal, community and environmental hygiene [28]. This poor state of hygiene is accounted for by the presence of immature stages of harmful microorganisms in the soil, in the air, on toilet door handles and on water closet handles [29]. These show the dynamic transmission network that exist in the Nigeria environment, through which pathogens infect human and animal hosts. Many factors have been shown to influence the bacterial transfers between surfaces, including the source and destination surfaces, bacterial species involved, moisture levels, pressure and friction between the contact surfaces and inoculums size on surfaces [30, 31].

The increasing incidence of epidemic outbreaks of certain diseases and its rate of spread from one community to the other has become a major public health concern [18]. Thus, with respect to literature that points out dangers associated with disease transmission through door handles this current study becomes necessary. The aim of this study was to assess the extent of microbial contamination of the door knobs in the offices of Nnamdi Azikiwe University Awka, Anambra State, Nigeria.

\section{Materials and Methods}

\subsection{Study Area}

Nnamdi Azikiwe University, Awka is one of the Federal universities in Nigeria. Its main campus is located in Awka 
which is the capital city of Anambra State, southeastern part of Nigeria. Geographically situated $6.242889^{\circ} \mathrm{N} 7.118289^{\circ} \mathrm{E}$. A microbial survey was done on door handles of different offices within the Nnamdi Azikiwe University Awka campus. A total of 6 buildings were randomly selected for the study namely: Faculty of Art (FA) complex, Faculty of Physical Science (FPS) complex, Faculty of Social Science (FSS) complex, Female hostel (FH) complex, Administrative Block $(\mathrm{AB})$ and the Medical Centre (MC).

\subsection{Specimen Collection}

A total of 432 office door handles from the randomly selected 6 buildings were swabbed using sterile swab sticks moistened with $5 \mathrm{ml}$ of sterile normal saline. This was accomplished in a tri-directional manner: up/down, left/right and diagonally, recapped and properly labelled. The samples were promptly transported to the Laboratory of the Faculty of Biosciences, Nnamdi Azikiwe University, Awka in an icecooled pack. These were examined for parasites. Forty out of the 423 specimens were cultured for bacterial and fungal isolation.

\subsection{Specimen Analysis}

\subsubsection{Parasitological Examination}

Parasitological examination was done as described by Cheesbrough [32]. The swab sticks were examined for parasites using sedimentation and floatation (Zinc sulphate techniques) after washing out the specimen using normal saline. The smeared specimen was stained with Ziehl Neelson's staining method for identification of parasite oocysts.

\subsubsection{Bacterial Isolation}

This was done according to Cheesbrough, [33] and Holt et al., [34]. Each sample was inoculated onto nutrient agar (oxoid) and MacConkey agar (oxoid) plates and incubated invertedly for 24 hours at $37^{\circ} \mathrm{C}$. Isolated colonies were then sub-cultured onto fresh nutrient agar (oxoid) and SalmonellaShigella (oxoid) agar plates for proper preliminary identification. Single isolated colonies from these plates were subjected to Gram's staining and standard biochemical tests (catalase, coagulase, oxidase, indole, Methyl red test, motility and Voges-proskauer (VP) tests).

\subsubsection{Data Analysis}

The data collected were subjected to statistical analysis using SPSS version 23.0. Chi-square ( $\chi 2)$ and Analysis of Variance (ANOVA) was used to test for significant differences in the distribution of microorganisms among office door handles.

\section{Results}

Of the 432 door handles examined in Nnamdi Azikiwe University, Awka, 136 (30.8\%) were contaminated. The highest number of contaminated doors were found in Medical Centre $41(30.1 \%)$ and the least in the Faculty of Social Sciences Complex 10 (7.4\%). E. histolytica 52 (38.2\%) was the highest parasite encountered, followed by $A$. lumbricoides $37(27.2 \%)$ while the least parasite was $E$. vermicularis 2 (1.5\%). The proportion of infected doors as well as the distribution of different species parasites in the door handles of different complexes examined was significant $(\mathrm{P}<0.05)$ [Tables 1 and 2].

Of 432 office door handles examined, 263 (60.9\%) yielded bacterial growth. A total of 7 colonies were obtained with 3 being Gram positive and 4 Gram negative. Biochemical analysis of bacterial isolates from the door samples revealed contamination from 7 bacterial species which include: Staphylococcus spp., Bacillus spp., Escherichia coli, Klebsiella sp., Salmonella, Micrococcus sp., Pseudomonas sp., of which most are associated the human skin flora. Most organisms are catalase positive while all the organisms tested negative to methyl-red and Voges-proskauer (VP) tests (Table 3).

Female hostel $72(27.4 \%)$ had more bacterial contamination while Faculty of Social Sciences 25 (9.5\%) had the least. Staphylococcus spp 54 (20.5\%) was the highest bacteria isolated, followed by Escherichia 53 (20.2\%) while Klebsiella $53(20.2 \%)$ was the least. The distribution of different species of bacteria in the door handles in different complexes was significant $(\mathrm{P}<0.05)$ [Table 3 ].

Table 1. Proportion of infected Office Doors handles in Nnamdi Nnamdi Azikiwe University Awka, Anambra State, Nigeria.

\begin{tabular}{lll}
\hline Buildings & Number of doors examined parasites (\%) & Number contaminated with \\
\hline FA & 72 & $27(19.8)$ \\
FSS & 72 & $10(7.4)$ \\
MEDC & 72 & $41(30.1)$ \\
AB & 72 & $15(11.0)$ \\
FH & 72 & $24(17.6)$ \\
FPS & 72 & $19(14.0)$ \\
Total & 432 & $136(30.8)$ \\
\hline
\end{tabular}

$\mathrm{P}$ value $=0.000(\mathrm{P}<0.05)$

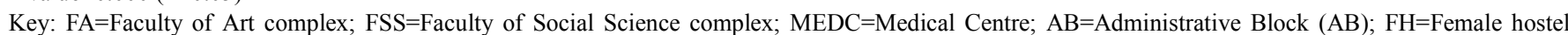
complex; FPS=Faculty of Physical Science complex 
Table 2. Parasite Species identified on the examined Office Door Handles in Nnamdi Nnamdi Azikiwe University Awka, Anambra State, Nigeria.

\begin{tabular}{|c|c|c|c|c|c|c|c|c|}
\hline Buildings & $\begin{array}{l}\text { Entamoeba } \\
\text { histolytica (Cyst) }\end{array}$ & Cryptosporidium & $\begin{array}{l}\text { Giardia } \\
\text { lamblia }\end{array}$ & $\begin{array}{l}\text { Ascaris } \\
\text { lumbricoides }\end{array}$ & $\begin{array}{l}\text { Trichuris } \\
\text { trichuira }\end{array}$ & Hookworm & $\begin{array}{l}\text { Enterobius } \\
\text { vermicularis }\end{array}$ & Total (\%) \\
\hline FA & $3(69.4)$ & $2(43.1)$ & $6(8.3)$ & $13(34.7)$ & $3(4.2)$ & $0(0.0)$ & $0(0.0)$ & 27 (19.9) \\
\hline FSS & $5(47.2)$ & $0(0.0)$ & $0(0.0)$ & $3(16.7)$ & $0(0.0)$ & $2(4.2)$ & $0(0.0)$ & $10(7.4)$ \\
\hline MEDC & $15(59.7)$ & $2(31.9)$ & $5(13.9)$ & $6(38.9)$ & $3(4.2)$ & $10(0.0)$ & $0(0.0)$ & $41(30.1)$ \\
\hline $\mathrm{AB}$ & $8(61.1)$ & $0(0.0)$ & $0(0.0)$ & $2(18.1)$ & $1(4.2)$ & $3(4.2)$ & $1(2.8)$ & $15(11.0)$ \\
\hline FH & $17(63.9)$ & $0(0.0)$ & $0(0.0)$ & $4(27.8)$ & $1(7.0)$ & $1(11.1)$ & $1(0.0)$ & $24(17.6)$ \\
\hline FPS & $4(47.2)$ & $1(33.3)$ & $1(1.4)$ & $9(11.1)$ & $2(1.4)$ & $2(0.0)$ & $0(0.0)$ & $19(14.0)$ \\
\hline
\end{tabular}

$\mathrm{P}$ value $=0.002(\mathrm{P}<0.05)$

Key: FA=Faculty of Art complex; FSS=Faculty of Social Science complex; MEDC=Medical Centre; AB=Administrative Block (AB); FH=Female hostel complex; FPS=Faculty of Physical Science complex

Table 3. Characteristics of Bacterial isolates from the selected Office door handles.

\begin{tabular}{|c|c|c|c|c|c|c|c|}
\hline $\begin{array}{l}\text { Characteristics of } \\
\text { organisms }\end{array}$ & Staphylococcus spp & Bacillus spp & Micrococcus spp & Escherichia spp & Klebsiella spp & Salmonella spp & Pseudomonas spp \\
\hline Cell morphology & Cocci & Rod & Cocci & Rod & rod & cocci & rod \\
\hline Gram staining reaction & + & + & + & - & - & - & - \\
\hline Catalase & + & + & + & + & - & - & + \\
\hline Coagulase & + & - & + & - & - & + & - \\
\hline Methyl red & - & - & - & - & - & - & \\
\hline $\mathrm{VP}$ & - & - & - & - & - & - & \\
\hline Oxidase & - & + & - & & - & - & + \\
\hline Motility & - & + & - & + & - & - & + \\
\hline Maltose & - & + & + & ++ & & & \\
\hline Sucrose & -+ & ++ & + & -+ & - & + & ++ \\
\hline Lactose & -+ & ++ & & ++ & ++ & - & - \\
\hline Glucose & ++ & ++ & + & ++ & + & ++ & + \\
\hline Fructose & ++ & ++ & & ++ & & - & \\
\hline
\end{tabular}

+ positive, - negative, ++ positive with gas production, -+ negative with gas production, Spp species.

Table 4. Prevalence of Bacterial Isolates on the selected Office Door handles examined.

\begin{tabular}{|c|c|c|c|c|c|c|c|c|}
\hline Buildings & Staphylococcus spp & Bacillus spp & Micrococcus spp & Escherichia spp & Klebsiella spp & Salmonella spp & Pseudomonas spp & Total (\%) \\
\hline FA & $6(11.1)$ & $0(0.0)$ & $11(39.2)$ & $10(18.9)$ & $4(20.0)$ & $6(14.6)$ & $5(13.5)$ & $42(16.0)$ \\
\hline FSS & $8(14.8)$ & $0(0.0)$ & $2(7.1)$ & $6(11.3)$ & $0(0.0)$ & $4(9.8)$ & $5(13.5)$ & $25(9.5)$ \\
\hline MEDC & $8(14.8)$ & $6(20.0)$ & $3(10.7)$ & $13(24.5)$ & $0(0.0)$ & $9(22.0)$ & $11(29.7)$ & $50(19.1)$ \\
\hline $\mathrm{AB}$ & $9(16.7)$ & $10(33.3)$ & $4(14.2)$ & $5(9.4)$ & $6(30.0)$ & $0(0.0)$ & $3(8.1)$ & $37(14.1)$ \\
\hline FH & $17(31.4)$ & $14(46.7)$ & $6(21.4)$ & $11(20.8)$ & $6(30.0)$ & $12(29.3)$ & $6(16.2)$ & $72(27.4)$ \\
\hline FPS & $6(11.1)$ & $0(0.0)$ & $2(7.1)$ & $8(15.1)$ & $4(20.0)$ & $10(24.4)$ & $7(18.9)$ & $37(14.1)$ \\
\hline Total & $54(20.5)$ & $30(11.4)$ & $28(10.6)$ & $53(20.2)$ & $20(7.6)$ & $41(15.6)$ & $37(14.1)$ & 263 \\
\hline
\end{tabular}

$P$ value $=0.000(P<0.05)$

Key: FA=Faculty of Art complex; FSS=Faculty of Social Science complex; MEDC=Medical Centre; AB=Administrative Block (AB); FH=Female hostel complex; FPS=Faculty of Physical Science complex

\section{Discussion}

This study has revealed the occurrence of the cysts, oocysts and ova of several parasitic protozoans and helminthes as well as different species of Bacteria on office door handles in selected offices of Nnamdi Azikiwe University, Awka, Anambra State, Nigeria. In this study, $30.8 \%$ of the office door handles were contaminated with parasites. Most of the parasite species which were encountered in this study have also been reported in other contact surfaces in previous studies. The contamination rate of this study was higher than the overall prevalence of $8.8 \%$ in computer keyboards and mouse in internet cafes by Ndams and Jimoh [35]; but lower than 33.3\% reported by Orji et al, [36] on dirty currency notes, $41.6 \%$ by Ngoda [29] on toilet and bathroom door handles/knobs and
$65.7 \%$ by Aminu et al [37] in fomites.

This indicates that door handles are repositories of resistant stages of important medical and veterinary parasites. The presence and isolation of resistant stages of such a high diversity of parasites from door handles reflect the unhygienic nature of some of the large number of humans that make daily visits to schools for various programmes. It is therefore plausible that the heavy contaminations observed on door handles in this study could be traced to very poor personal hygiene of such persons. This implies that hand washing after toilet usage is not being done properly leading to adherence of these enteric organisms on human hands which are eventually deposited on door handles. Hands appear to be the most vulnerable parts of the human body that are used to operate and or in contact virtually with the 
entire door handles in this study. Thus humans who work in and or transact businesses in these contaminated environments could be at the risk of being infected by some of the encountered parasites.

Medical Centre had the highest parasite contaminated doors. This could be as a result of the category of people visiting the Medical Centre. Other offices may have been occupied or visited by healthy workers and visitors but majority of people visiting the Medical Centre are sick people which are already debilitated with different types of infection. Since people with different types of ailment are using the doors, going into consulting rooms, pharmacy for drugs and laboratories, the doors in Medical Centre is prone to contamination more than other doors examined.

E. histolytica and A. lumbricoides were the most dominant parasites encountered. Incidentally, the cysts of $E$. histolytica and ova of $A$. lumbricoides are infective and these two parasites are most likely to be contracted in school environments. They can withstand disinfectants used on contact surfaces [38]. Ibidapo and Okwa [39] attributed the ubiquity of Ascaris lumbricoides to high resistance of its ova to harsh environmental conditions. Cysts of E. histolytica, Giardia spp. and oocysts of Cryptosporidium spp. have thick walls that could withstand desiccation and preserve their infectivity [40]. It must be noted that this study was done in the warm months of the year. This as well as the tropical climate provide a conducive atmosphere for the development of these parasites [41, 42].

A total of $60.9 \%$ of the office door handles yielded bacterial growth. This was less than $64.5 \%$ bacterial contamination recorded by Abiose, [43] in Adekunle Ajasin University, Akungba -Akoko, Ondo State, Nigeria; 75.29\% reported by Tiku et al., [19] in door handles in University of Calabar Community; $86.7 \%$ by Nworie et al [18] in door handles of public conveniences in Abuja; 87.1\% reported by Al-Harbi et al., [44] in frequently used Fomites in Kuwait. However, it was higher than $43.5 \%$ of the bacterial contamination recorded by Hisham, [45] in office door handles of different universities in Khartoum State; 20.33\% by Omololu-Aso et al, [46] in door knobs in Obafemi Awolowo University Teaching Hospital Complex, Ife, Nigeria and $16.11 \%$ reported by Ajenifuja and Ajibade, [47] on computer mouse and keyboard in Ado-Ekiti, Nigeria. The difference may be as a result of differences in location as well as environmental factor such as sanitation. Contamination on these door handles may have been as a result touching the door handle with an already contaminated hand. Previous studies have shown that frequently used fomites were most likely contaminated and carried higher loads of heterotrophic bacteria [8].

The present study demonstrated that majority of the bacteria, transmitted through door handles are Gram negative. Staphylococcus and Escherichia spp were predominant bacteria encountered while Klebsiella was the least. This is in line with the work of Alonge et al., [48] in Baze University Abuja, Odigie et al. [5] in Benin City, Lincy et al. [49] in India and Bhatta et al. [50] in Nepal. The presence of
Escherichia spp, Salmonella spp, Klebsiella spp, infers contamination by faecal matter, suggesting poor hygienic practices of improper washing of hands after visiting toilets before opening the office doors. The presence of Pseudomonas spp, a predominant soil bacterium, suggest transmission brought in from foot wears and settling dust suspensions. Bacillus isolated could be explained by their spore forming ability which made it to be able to resist harsh environmental condition, withstand dry heat and certain chemical disinfectants for a considerable period. The isolated bacterial pathogen on door handles in this study are consistent with the findings of other researchers [51, 18, 52, 5], with Staphylococcus spp being the most prevalent. Contamination by Staphylococcus aureus, a bacterium of the skin flora, suggests direct contact of the doors by individual handlers [53-55]. Staphylococcus and Pseudomonas have been linked to urinary tract infections, bacterial diarrhoea, bacterial meningitis and bacterial pneumonia [56].

Female hostel had the highest bacterial isolates on the door handles. This is in agreement with the findings of Nworie et al., [18], Flores et al., [54]. This could be as a result of possible sanitation and personal hygienic standard of the users. This is in accordance with the work of Boone and Gerba [11], who also reported that the level of contamination varies depending on the traffic exposure and the environment. Baadhaim et al., [57] and Oranusi et al [31] indicated that the door handles may aid in the spread of microbes between individuals and that they may be a reservoir of microbial contamination.

\section{Conclusion}

These results obtained from these studies showed high level of microbial contamination on the office door handles which are underestimated as source of contamination of human hands with potentially pathogenic bacteria and parasites and thus a possible cause of self-infection or cross infection to others. Given the potential of transmission of enteric pathogens amongst human subjects in the school, improved sanitary and control measures such as internal control policy for routine disinfection and the choice of disinfectants as well as treating contaminated facilities by installing secondary disinfection systems (ultraviolet lamps or ozone disinfection systems) is also important, while also maintaining good personal hygienic practices to prevent the transfer and spread of pathogens from these fomites. Considering factors like the number of sites, the number of samples collected, conditions under which the research work was carried out, further studies are recommended to validate the results of the present study by using more different culture media.

\section{Acknowledgements}

We wish to acknowledge the staff of Nnamdi Azikiwe University, Awka, Anambra State, Nigeria for their cooperation and assistance during sample collection and analysis. 


\section{References}

[1] Eltablawy S. Y. and Elhinfnawi H. N. (2009). Microbial Contamination of Some Computer Keyboards and Mice in National Center for Radiation Research and Technology (NCRRT). World Applied Sciences Journal 6 (2): 162-167.

[2] Apichai, S., Boonchai, W., Chittima, P., Oralak, S., Fukuda, C. D., Ladaporn, B. and Mason, C. J. (2005). Re-evaluation of commercially Available Enzyme-Linked immunosorbent assay for the detection of Giardia lamblia and Cryptosporidium spp. from stool specimens. Southeast Asian Journal of Tropical Medicine and Public Health, 36 (4): 2629.

[3] Kraay A. N. M., Michael A. L. Hayashi M. A. L., HernandezCeron N., Spicknall I. H., Eisenberg M. C., Meza R and Eisenberg J. N. S (2018). Fomite-mediated transmission as a sufficient pathway: a comparative analysis across three viral pathogens. BMC Infectious Diseases 18: 540.

[4] Neely A. and Sittig D. F. (2002). Basic microbiologic and infection control information to reduce the potential transmission of pathogens to patients via computer hardware. Journal of the American Medical Informatics Association 9 (5): 500-508.

[5] Odigie A. B., Ekhiase F. O., Orjiakor P. I. and Omozuwa S. (2017). The role of door handles in the spread of microorganisms of public health consequences in university of Benin teaching hospital (UBTH), Benin City, Edo State. Pharmaceutical Science and Technology 2 (2): 15-21.

[6] Li S., Eiseberg J. N. S., Sicknall I. H. and Koopman J. S. (2009): Dynamics and control of infections transmitted from person to person through the environment. American Journal of Epidemiology, 170 (2): 257-265.

[7] Eiref S. D, Leitman I. M. and Riley W. (2012). Hand Sanitizer Dispensers and associated Hospital-acquired infections: Friend or Formite? Surgical Infections 13 (3): 137-140.

[8] Lopez G. U., Gerba C. P., Tamimi A. H., Kitajima M., Maxwell S. L. and Rose J. B. (2013). Transfer efficiency of bacteria and viruses from porous and nonporous fomites to fingers under different relative humidity conditions. Applied and Environmental Microbiology 79, 5728-34 (2013).

[9] Osterholm M. T., Hederg C. W. and MacDonald K. L. (1995): Epidemiology of infectious diseases. In: Mandell, Douglas and Bennett's principles and Practice of Infectious diseases Vol. I, 4th edition. Churchill-Livingstone, New York. P. 165.

[10] Bright KR, Boone SA, Gerba CP. (2010): Occurrence of bacteria and viruses on Elementary classroom surfaces and the potential role of Elementary Classroom hygiene in the spread of infectious diseases. The Journal of School Nursing, 26 (1): 33-41.

[11] Boone, S. A. and Gerba, C. P. (2010): The prevalence of human Para-influenza virus on indoor office fomites. Food and Environmental Virology 2 (1): 41-46.

[12] Shiferaw T., Beyene G., Kassa T. and Sewunet T. (2013). Bacterial contamination, Bacterial Profile and Antimicrobial Susceptibility Pattern of Isolates from Stethoscopes at Jimma University Specialized Hospital. Annals of Clinical Microbiology and Antimicrobials: 12: 39.
[13] Schmidt M. G., Attaway H. H., Sharpe P. A., John J., Sepkowitz K. A. and Morgan A. (2012). Sustained reduction of microbial burden on common hospital surfaces through introduction of copper. Journal of Clinical Microbiology 50: 2217-2223.

[14] Kramer A., Schwebke I. and Kampf G. (2006). How long do nosocomial pathogens persist on inanimate surfaces? A systematic review. BMC Infectious Diseases 6: 130.

[15] Carter M. J. (2005). Enterically infecting viruses: Pathogenicity, Transmission and Significance for food and water borne infections. Journal of Applied Microbiology 98: $1354-1380$.

[16] Reynolds K. A. (2005): Hygiene of Environmental Surfaces. International Journal of Environmental Health Research, 15 (3): $225-234$.

[17] Rusin, P., Maxwell, S. and Gerba, C. (2002). Comparative surface to hand and fingertip to-mouth transfer efficiency of gram-positive bacterial, gram- negative bacterial and phage. Journal of Applied Microbiology, 93: 585-592.

[18] Nworie. A., Ayeni. J. A., Eze U. A., and Azi. S. O. (2012). Bacterial contamination of door handles/knobs in selected public conveniences in abuja metropolis, nigeria; a public health threat. Continental Journal of Medical Research 6 (1): $7-11$.

[19] Tiku, D. R., Bassey, I. U. and Asikong, E. B. E (2019). Evaluation of Public Health Hazards of Door Handles in University of Calabar Community. International Journal of Scientific and Engineering Research 10 (Issue 6): 39-71.

[20] Tanner, D. (2009). Reduction in infection risk through treatment of microbially contaminated suffices with a novel, portable, saturated steam vapor disinfection system. American Journal of Infection Control, 37: 20-27.

[21] Clauditz, A., Resch, A., Wieland, K. P., Peschel, A. and Gotz, F. (2006). Staphyloxantin plays a roles in the fitness of Staphylococcus aureus and its ability to cope with oxidative stress. Infection and Immunity 74 (8), 4950-4953.

[22] Aiello A. E., Marshall B., Levy, S, B., Della-Latta P and Larson E. (2004). Relationship between Triclosan and susceptibilities of bacteria isolated from hands in the community. Antimicrobial Agents of Chemotherapy. 48 (8): 2973-2979.

[23] Chen, Y., Jackson, K. M., Chea, F. P. and Schaffner, D. W. (2001): Quantification and variability analysis of bacterial cross- contamination rates of common food service tasks. Journal of Food Protection, 64: 72-80.

[24] Roberts, L. and Janovy, J. (2009). Foundations of Parasitology. New York: McGraw Hill.

[25] Noble, E., Noble, G. A. Schad, G. A. and MacInnes, A. J. (1989). Parasitology. Philadelphia: Lea and Febiger. Nock I. $\mathrm{H}$ and Geneve A. I (2002): Public health significance of parasite cysts and egg on water closet handles. The Nigeria Journal of Parasitology 17: 1-94.

[26] Current, W. L. and Garcia, L. S. (1991). Cryptosporidiosis, Clinical Microbiology Reviews, 4: 325-358.

[27] World Health Organization (1997). Amoebiasis. WHO Weekly Epidemiologic Records, 72: 97-100. 
[28] Akogun O. B. (1989): Some social aspects of helminthiasis among the people of Gumaru district, Bauchi State. Nigeria Journal of Tropical Medicine and Hygiene; 92 (3): 193-196.

[29] Ngoda F. (2017). Assessment of Bacterial contamination of toilet and bathroom door handles/knobs at Daeyang Luke Hospital. Pharmaceutical and Biological Evaluations 4 (4): 193-197.

[30] Sattar S. A. (2001). Survival of microorganisms on animate and inanimate surfaces and their disinfection. In Rutala WA, editor, Disinfection, Sterilization and Antisepsis: principles and practices in healthcare facilities. Association for Professionals in Infection Control and Epidemiology, Inc., Washington D. C: 195-205.

[31] Oranusi S. U., Dahunsi S. O., Owoso O. O. and Olatile T. (2013). Microbial profiles of Hands, Foods, Easy contact surfaces and Food contact surfaces: A case study of a University Campus. Novus International Journal of Biotechnology and Bioscience 2 (1): 30-38.

[32] Cheesbrough, M. (2006a). Parasitological Tests. District Laboratory Practice in Tropical Countries Part 1. Cambridge Low-Price Edition, Cambridge University Press, United Kingdom: 1-258.

[33] Cheesbrough, M. (2006b). Microbiological tests, District Laboratory Practice in Tropical Countries Part 2, Second Edition, Cambridge Low-Price Edition, Cambridge University Press, United Kingdom: 1-154.

[34] Holt J. G., Krieg N. R., Sneath P. H., Staley J. T. and Williams S. T. (1994). Bergey's manual of Determinative Bacteriology, 9th edition. Baltimore, Md: The Williams \& Wilkins Co, Pp 787.

[35] Ndams, I. S. and Jimoh, O. I. (2006). Prevalence of Parasite Eggs and Cysts on Computer Mouse. Keyboards and Users of Internet Cafes, in Samaru, Zaria, Nigeria. The Zoologist, 1 (4): $80-85$

[36] Orji, N., Esiaka, E., Anyaegbunam, L., Obi, R. and Ezeagwuna, D. (2012). Parasite Contamination of Nigerian Currency (Paper and Polymer Notes) in Ihiala Local Government Area of Anambra State, Nigeria. The Internet Journal of Infectious Diseases, 10 (1): 20-25.

[37] Aminu M., Usman-Sani H. and Usman M. A. (2014). Characterization and determination of antibiotic susceptibility pattern of bacteria isolated from some fomites in a Teaching Hospital in Northern Nigeria. African Journal of Microbiology Research 8 (8): 814-818.

[38] Ajero, C. M., Nwoko, B. E. B., Nwoke, E. A. and Ukaga, C. N (2008). Human Amoebiasis: Distribution and Burden; and the Nigerian environment. International Science Research Journal, 1 (2): 130-134.

[39] Ibidapo, C. A. and Okwa, O. (2008). The prevalence and intensity of soil transmitted helminthes in a rural community, Lagos suburb, south west Nigeria. International Journal of Agriculture and Biology, 10: 89-92.

[40] Centers for Disease Control and Prevention - CDC (2010). Cryptosporidiosis surveillance and Giardiasis Surveillance. Surveillance Summaries, United States, 2006-2008. Morbidity and Mortality Weekly Report, 59: (No. SS-\#).

[41] Gaspard, P., Wiart, J. and Schwartzbrod, J. (1997). Parasitological contamination of urban sludge used for agricultural purposes. Waste Management Research 15: 429436.

[42] Umeanaeto, P. U, Nwofor, O. F, Iwueze, M. O., Ugwuanyi, I. K., Egbuche, C. M. and Igbodika, C. M. (2016). Parasite Contamination of Edible Vegetables sold in Onitsha Markets. The Bioscientist 4 (1): 21-31.

[43] Abiose O. F. (2019). Bacterial Contamination of Selected Public Toilet Door Handles within Adekunle Ajasin University Campus, Akungba-Akoko, Ondo State, Nigeria. International Journal of Sciences: Basic and Applied Research (IJSBAR) 43 (1): 76-86.

[44] Al-Harbi M., Anderson A., Elmi A. (2017). Evaluation of microbial contamination in frequently used Fomites in Kuwait. Biodiversity International Journal 1 (Issue 3): 80-86.

[45] Hisham A. A. S. (2015). Assessment of Gram-Negative Bacterial Contamination on Door Handles of Service Offices in Sudanese Universities, Khartoum State. A dissertation submitted in partial fulfillment for the requirements of MSc in Medical Laboratory Science (Microbiology): 1-34.

[46] Omololu-Aso, J., Kolawole, D. O., Omololu-Aso, O. O., and Ajisebutu, S O. (2011). Antibiotics sensitivity pattern of staphylococcus aureus from fomites in the ObafemiAwolowo University Teaching Hospital Complex (OAUTHC) Nigeria. International Journal of Medicine and Medical Sciences 3 (2): 32-36.

[47] Ajenifuja, O. A. and Ajibade, V. A (2012). Prevalence of Parasitic Eggs and Parasites Cysts on Computer Mouse and Keyboard in School of Science and Computer Studies of Federal Polytechnic, Ado-Ekiti, Nigeria. Global Journal of Science Frontier Research Bio-Tech and Genetics 12 (issue 4) version 1: 26-30.

[48] Alonge, O. O; Auwal B. M, Aboh M. I. (2019). Bacterial Contamination of Toilet door handles on Baze University Campus Abuja, Nigeria. African Journal of Clinical and Experimental Microbiology 20 (1): 35-41.

[49] Lincy M., Vidhya, Arunadevi, Ali P. S. S. and John J (2016). Determination of bacterial and fungal loads and antibiotic susceptibility testing of bacteria isolated from public toilet door handles in Vellore district, Tamilnadu, India. International Journal of Research in Biosciences 5 (Issue 4): 69-78.

[50] Bhatta D. R, Hamal D, Shrestha R, Subramanya SH, Baral N, Singh RK, Nayak N, and Gokhale S (2018). Bacterial contamination of frequently touched objects in a tertiary care hospital of Pokhara, Nepal: how safe are our hands? Antimicrobial Resistance and Infection Control. 7: 97.

[51] Baker J. and Bloomfield S. F. (2000). Survival of Salmonella in bathroom and toilets in homes. Journal of Applied Microbiology 89: 137-44.

[52] Maori L., Agbor V. O. and Ahmed W. A. (2013). The prevalence of bacterial organisms on toilet door handles in secondary schools in Bokkos L. G. A., Jos, Plateau Sate, Nigeria. Journal of Pharmaceutical and Biological Sciences 8 (4): 85-91.

[53] Lindberg E., Adlerberth B., Hesselmar R., Saalman I., Strannegared N. and Aberg A. (2004). High rate of transfer of Staphylococcus aureus from parental skin to infant gut flora. Journal of Clinical Microbiology 42: 530-534. 
[54] Flores G. E., Bates S. T., Knights D., Lauber C. L., Stombaugh J., Knight R. and Fierer N. (2011). Microbial Biogeography of Public Restroom Surfaces. PLoS ONE 6 (11): e28132.

[55] Alonge O. O., Wakkala F. I., Ogbaga C. C., Akindele K. A. (2017). Bacterial analysis of barbecued meat (Suya) from selected locations within Abuja, Nigeria. Proceedings of the 13th International Conference on Electronics, Computer and Computation (ICECCO), Abuja, Nigeria. pp. 1-5.
[56] Willey J. M., Sherwood LM, Woolverton C. J. (2008). Prescott, Harley, and Klein's Microbiology, 7th edition. McGraw Hill Company Incorporated. New York. pp. 1088.

[57] Baadhaim M., Kusner, D. and Ahmed H. (2011). Distribution and Prevalence of Bacteria Found on the Door Handles of Olin Hall, Drake University. Conference Poster. 